\title{
ОБРАЗОВАТЕЛЬНОЕ ПРАВО
}

\section{EDUCATION LAW}

DOI: $10.22363 / 2313-2337-2020-24-2-252-273$

Научная статья

\section{ЛОКАЛЬНЫЕ АКТЫ ВУЗОВ КАК СРЕДСТВО ПРОТИВОДЕЙСТВИЯ КОРРУПЦИИ}

\author{
А.В. Габов ${ }^{1}$ О.А. Ястребов ${ }^{2}$ \\ ${ }^{1}$ Институт государства права Российской академии наук \\ 119019, г. Москва, Российская Федераџия, ул. Знаменка, д. 10 \\ ${ }^{2}$ Российский университет дружбы народов \\ 117198 , г. Москва, Российская Федераџия, ул. Миклухо-Маклая, д. 6
}

Целью статьи является анализ такого правового средства противодействия коррупции, как кодексы этики. Авторы анализируют коррупцию в сфере высшего образования; указывают, что вред от нее носит кумулятивный характер. Отмечается, что в настоящее время законодательство не ограничивается противодействием коррупции в органах государственной власти. Закон о противодействии коррупции с 2012 г. определяет обязанность каждой организации принимать меры по противодействию коррупции. Авторы показывают на примерах документов организаций высшего образования, что надлежащему исполнению этой обязанности со стороны таких организаций уделяется все большее внимание. При этом механизм использования положений этических кодексов тесно переплетается с иными средствами предупреждения и противодействия коррупции, используемыми образовательными организациями. Также отмечается, что положения, содержащиеся в этических кодексах, утрачивают свою природу и «перерастают» в нормы правовые.

Ключевые слова: коррупция, образовательная организация, высшее образование, противодействие коррупции, кодекс этики

Конфликт интересов. Авторы заявляют об отсутствии конфликта интересов.

(C) Габов А.В., Ястребов О.А., 2020.

This work is licensed under a Creative Commons Attribution 4.0 International License

https://creativecommons.org/licenses/by/4.0 


\title{
Для цитирования:
}

Габов А.В., Ястребов О.А. Локальные акты вузов как средство противодействия коррупции // Вестник Российского университета дружбы народов. Серия: Юридические науки. 2020. T. 24. № 2. C. 252-273. DOI: 10.22363/2313-2337-2020-24-2-252-273.

Дата поступления в редакиию: 06 февраля 2020 г.

Дата принятия к печати: 10 апреля 2020 г.

DOI: $10.22363 / 2313-2337-2020-24-2-252-273$

Research Article

\section{LOCAL ACTS OF UNIVERSITIES AS A MEANS OF COMBATING CORRUPTION}

\author{
Andrey V. Gabov ${ }^{1}$, Oleg A. Yastrebov ${ }^{2}$ \\ ${ }^{1}$ Institute of State and Law of the Russian Academy of Sciences \\ 10 Znamenka str., 119019, Moscow, Russian Federation \\ ${ }^{2}$ Peoples' Friendship University of Russia (RUDN University) \\ 6 Miklukho-Maklaya str., 117198, Moscow, Russian Federation
}

\begin{abstract}
The purpose of the article is to analyze such a relatively new legal means of combating corruption as codes of ethics. The authors note the harm caused by corruption in higher education; they point out that such harm is cumulative. It is noted that currently the legislation is not limited to combating corruption in public authorities. The anti-corruption law since 2012 defines the obligation of each organization to take measures to combat corruption and take the necessary measures to do so. The authors conclude that more and more attention is being paid to the proper performance of this duty by organizations. At the same time, the mechanism for implementing provisions of ethical codes is closely intertwined with other anti-corruption tools used by universities. It is also noted that the provisions contained in the ethical codes lose their nature and "grow" into legal norms.
\end{abstract}

Key words: corruption, educational organization, higher education, anti-corruption, code of ethics

Conflicts of interest. The authors declared no conflicts of interest.

\section{For citation:}

Gabov, A.V., Yastrebov, O.A. (2020) Local acts of Universities as a means of combating corruption. RUDN Journal of Law. 24 (2), pp. 252-273. DOI: 10.22363/2313-2337-202024-2-252-273.

Article received February 06, 2020

Article accepted April 10, 2020 


\section{Введение. Постановка проблемы}

Российская правовая система в последние годы сделала существенный прорыв в части формирования корпуса нормативных положений, направленных как на превенцию коррупционных проявлений в различных сферах общественной и государственной жизни, так и на установление ответственности за коррупционные правонарушения. В исследованиях справедливо отмечается, что «противодействие коррупции и борьба с ней приобрели в России системный и наступательный характер» (Khabrieva, 2016:21).

Этот вывод касается как ситуации в стране в целом (во всех сферах), так и в сфере образования и науки в частности.

Несмотря на то, что сфера высшего образования не является (по различным докладам ${ }^{3}$ ) наиболее проблемной сферой с точки зрения распространения коррупционного поведения (отметим, что в 2019 г. Министерство науки и высшего образования Российской Федерации получило около 600 обращений с жалобами на коррупцию $\left.{ }^{4}\right)$, тем не менее, как отмечают исследователи, проблемы противодействия коррупции в ней уже длительное время остаются в фокусе активного внимания со стороны органов государственной власти, институтов гражданского общества, общественных организаций (Plyugina, 2016:123-124) (отметим, что коррупция в образовании является общемировой проблемой, а не только российской5 ). Можно встретить оценки, согласно которым в настоящее время в этой сфере нет организаций, свободных от отдельных проявлений или от очагов коррупции (Stavilo, 2008). Здесь, впрочем, важны не количественные оценки. Коррупция относится к числу таких явлений, о которых судят не по статистике, а по тому, что граждане наблюдают в реальной жизни, в том числе черпая сюжеты из средств массовой информации. Один раз, столкнувшись с негативными примерами, граждане, как правило, проецируют их на всю систему образования в целом. Недаром социологи довольно давно подметили - в общественном сознании образование - одна из наиболее коррумпированных cфep (Gorshkov, Markin 2012: 225).

Причин для такого восприятия немало: даже беглый анализ средств массовой информации за последние годы позволяет собрать десятки (если не сотни)

\footnotetext{
${ }^{3}$ См.: Генпрокуратура назвала лидеров по уровню коррупции - силовики, суды, исполнительная власть, available at: https://pasmi.ru/archive/245653/ (Accessed 13 January 2020).

${ }^{4}$ См.: Минобрнауки получило около 600 обращений с жалобами на коррупцию, available at: https://ria.ru/20191204/1561936578.html (Accessed 01 February 2020).

5 Здесь нельзя не привести слова Vincent R. Johnson по этому поводу, сказанные в работе 2008 г.: «In every educational institution, in every country and generation, there is a struggle between corrupt practices and the continuing quest for high ethical standards», см.: (Johnson, 2008:1)). Существуют и опубликовываются специальные исследования по этим вопросам, к примеру, см.: (Glendinning, Orim, King, 2019; Heyneman, 2004:637-648).
} 
материалов (сообщений) о фактах коррупции в образовательных организациях, которые в абсолютном большинстве случаев заканчиваются вынесением обвинительных приговоров. Наиболее общественно-опасные коррупционные нарушения в сфере высшего образования можно сгруппировать следующим образом:

- взяточничество и коммерческий подкуп за сдачу экзамена, поступление в образовательную организацию и прочее ${ }^{6}$. Примеров такого рода абсолютное большинство, и фабула дел здесь не отличается оригинальностью от года к году: можно посмотреть имеющиеся примеры 2013 г. ${ }^{7}, 2017$ г. $^{8}$, и прошлого 2019 г. ${ }^{9}$; такие действия часто сопряжены с подлогом ${ }^{10}$;

\footnotetext{
${ }^{6}$ Исследователи проблем коррупции указывают, что взятки являются «основным проявлением коррупции» в сфере образования, см.: (Damaskin, 2009:15).

${ }^{7}$ «...Собранные Шахунским межрайонным следственным отделом Следственного комитета доказательства признаны судом достаточными для вынесения приговора бывшему директору Шахунского филиала ВУЗа, обвиняемого в получении взятки. Как сообщает пресс-служба СУ СК РФ по Нижегородской области, следствием и судом установлено, что 25 февраля 2013 года директор учебного заведения, находясь на рабочем месте в помещении Шахунского филиала высшего учебного заведения, расположенного в Шахунье, получила от студентов по специальности «Финансы и кредит» через посредника взятку в размере 50 тысяч рублей за успешную сдачу государственного экзамена и защиту дипломных работ. Приговором суда подсудимой было назначено наказание в виде штрафа в сумме 1,5 миллиона рублей» (см.: Директор филиала вуза в Нижегородской области признали виновной во взяточничестве, available at: http://newsroom24.ru/news/criminal/72266/?sphrase_id=300373 (Accessed 13 December 2019).

8 «...На скамье подсудимых оказался доцент кафедры «Оборудование и технология сварочного производства» филиала ДГТУ в Таганроге. Его обвинили в получении взятки и мошенничестве. По версии следствия, 31 января этого года преподаватель получил от студента деньги за «сдачу» экзамена. Три отметки, проставленные им в зачетную книжку, педагог оценил в 20 тысяч 500 рублей. Студенту он сообщил, что может также посодействовать в положительной сдаче и других дисииплин, которые сам не преподавал. В этот же день получил от учащегося еще 22 тысячи 500 рублей, но вскоре был задержан сотрудниками полиции. Подсудимого приговорили к четырем годам лишения свободы с отбыванием наказания в исправительной колонии общего режима. Также ему три года запрещено преподавать, - сообщили в Ростовском областном суде» (см.: Илюхина Д. Преподаватель донского вуза осужден за взятку, available at: https://161.ru/text/gorod/51654771/, 4 декабря 2017).

9 «Доцент аграрного университета за взятки ставил оценки студентам. Как сообщили в Советском районном суде, доцент кафедры «Философии, политологии и права» ВолГАУ... получал взятки от студентов через посредника. За денежное вознаграждение преподаватель факультета сервиса и туризма принимал экзамены. Размер взятки не превышал 10 тысяч рублей. Противоправная деятельность преподавателя была пресечена сотрудниками отдела экономической безопасности и противодействия коррупции ГУ МВД совместно с коллегами из УФСБ. Расследованием занимался региональный следственный комитет. Накануне Советский районный суд огласил приговор.... За взятки... отделался штрафом в размере 150 тысяч рублей» (см.: Абрамов А. Волгоградский преподаватель заплатит штраф за взятки, available at: https://volga-kaspiy.ru/courtroom/volgogradskiy-prepodavatel-zaplatit-shtrafza-vzyatki.html (7 Февраля 2019 г.)).

10 «В Магнитогорске Челябинской области преподаватель университета ставил студентам зачеты за деньги. Решением суда мужчине назначено уголовно-правовое наказание. Об этом сообщили в прессслужбе региональной прокуратуры. В Ленинском районном суде установлено, что старший преподаватель кафедры «Спортивное совершенствование» МГТУ имени Носова... получил мелкие взятки от пяти студентов на общую сумму 3900 рублей. После этого мужчина внес в документы ложные сведения о сдаче студентами зачета. Суд признал преподавателя виновным по части 1 статьи 291.2 УК РФ «мелкое взяточничество» и части 1 статьи 292 УК РФ «служебный подлог» и назначил наказание в виде штрафа в размере 20 тысяч рублей» (см.: Преподавателя МГТУ поймали на взятках, available at: https://telefakt.ru/ lenta/prepodavatelya_mgtu_pojmali_na_vzyatkax.html (16 мая 2019 г.)).
} 
— получение денежных средств за сдачу экзаменов или посредничество в получении денежных средств лицом, от которого зависит оценка экзаменуемого при отсутствии реальной возможности влияния (квалифицируется как мошенничество в практике);

- различного рода нарушения при осуществлении закупочной деятельности из числа тех, что вызваны реальным конфликтом интересов;

- хищение денежных средств через их начисление и выплату «мертвым душам» или через повышенные премии с возвращением части таких средств организаторам коррупционных схем (такие нарушения в настоящее время квалифицируются как мошенничество). В качестве примера можно привести недавний пример с задержанием руководства одного из вузов Воронежа, где «по версии следствия, ректор в течение пяти лет получал от полутора десятков подчиненных... наличными выписанные им премии в обмен на покровительство» ${ }^{11}$.

Вред от коррупции в высшем образовании (впрочем, как и в образовании вообще) имеет кумулятивный характер.

На первый взгляд, перед нами обычные экономические потери. На самом деле вред значительно больше и «длиннее» по времени воздействия. Отдельные авторы указывают, что такой вред выражается в этических потерях, подрыве моральных устоев общества (Aliev, Solovykh, 2019:46-50).

Но ситуация еще хуже: коррупция ведет к появлению лиц, лишь формально владеющих необходимыми квалификационными навыками, знаниями. В результате такие лица, попадая в профессиональную среду, в которой осуществляются высокорисковые виды деятельности, подвергают опасности жизнь и здоровье людей. Коррупция в высшем образовании ведет к постоянному воспроизводству такого рода «специалистов», что помимо прочего служит демотивирующим некоторые исследователи здесь используют слово «деморализующим» (Johnson, 2008:4) фактором (для действительно талантливой молодежи (как обучающихся, так и преподавателей ${ }^{12}$ ), невозможности роста талантливых и профессиональных специалистов. Гжегож В. Колодко, польский экономист, исследуя проблемы экономик переходного периода, оценивая вред от коррупции для экономики в целом, среди прочего констатировал, что «коррупция ослабляет мотивацию»; он отмечал, что коррупция влечет снижение стремления «напряженно трудиться и уважать законы», в конечном итоге, замечает Гжегож В. Колодко, это может «сказаться на качестве человеческого капитала, утратившего стимуль к совериенствованию своих навыков» (Kolodko, 2000:162) (данный автор в отношении вреда коррупции также использовал выражение «коррупция — это обреченность надежд»).

\footnotetext{
${ }^{11}$ См.: Калашников С., Цветков А. Ректор премировал себя за счет подчиненных, available at: https://www.kommersant.ru/doc/4275475 (Accessed 07 March 2020).

${ }^{12}$ О демотивирующем влиянии коррупции также см.: (Khabrieva, 2012:499 - 508), авторы главы А.В. Габов, А.Е. Молотников.
} 
Последствие коррупции в высшем образовании - снижение доверия к сфере образования, как у граждан, так и у иностранцев - потенциальных абитуриентов российских образовательных организаций. Как отмечает Стивен. П. Хейнеман, «в ряде случаев коррупция настолько проникает во все сферы университетской деятельности, что доверие к результатам исследований и выданным дипломам оказывается под вопросом. Следствием этого становится снижение рентабельности инвестиций в сферу высшего образования как отдельных людей, так и общества в целом. Академическая репутация некоторых стран настолько испорчена, что под вопросом находится как качество вылданных в этих странах дипломов, так и качество вузов» (Heyneman, 2014:8). Результаты этого - не просто прямые экономические потери для образовательных организаций и бюджета, но и снижение конкурентоспособности страны в целом, снижение возможностей ее влияния на окружающий мир $^{13}$, уменьшение ее «мягкой силы».

Специфика коррупции в сфере образования состоит в том, что коррупционные связи складываются в течение длительного периода времени и охватывают значительное количество участников как внутри организации, осуществляющей образовательную деятельность, так и вне ее. Исследователи проблем противодействия коррупции в образовании (И.В. Плюгина), для квалификации коррупции в этой сфере используют слова «системный характер» (Putilo, Volkova 2015:222). Именно поэтому для противодействия коррупции необходима системная работа с вовлечением в нее и преподавателей, и обучающихся. Совершенно правильно подметил М.М. Котюков ${ }^{14}$, отвечая на вопрос о том, возможно ли искоренить коррупцию в вузах, что работа по избавлению от коррупции - это дорога всегда с двусторонним движением - со взяточничеством должны бороться как студенты, так и преподаватели; с одной стороны, к взяточничеству должны нетерпимо относиться в самом преподавательском сообществе, а с другой - студенты должны понимать, что это не есть та практика, которой нужно придерживаться ${ }^{15}$.

Одно из правовых средств, представляющих как раз пример такой дороги с двусторонним движением - внутренние (локальные) документы образова-

\footnotetext{
${ }^{13}$ Практически общим стало понимание образования сегодня как одной из статьи экспорта и как способа перемещения на территорию определенных государств талантливой молодежи: «High school as an instrument of international competition. The global market of educational services, higher education has become an international business, and the export of educational services has become a significant sector of economies of different countries. Modern universities have become a way of attraction of young people from wide ranges of education, selection of them, general cultural and vocational training. Educational migration allows countries with an aging population and its natural decrease (Europe, Canada and others) to support the population and provide high quality human capital» см.: (Efimov, Lapteva, 2011:149).

${ }^{14}$ На тот момент - Министр высшего образования и науки Российской Федерации.

${ }^{15}$ Минобрнауки получило около 600 обращений с жалобами на коррупцию, available at: https://ria.ru/20191204/1561936578.html (Accessed 01 February 2020).
} 
тельных организаций, целью которых является установление этических норм поведения.

\section{Правовая природа локальных документов, содержащих этические нормы. Примеры применения}

Интересно, что изначально, когда создавалось современное законодательство о противодействии коррупции, ничего не предвещало роста интереса к такому инструменту. Отчасти потому, что коррупция рассматривалась применительно к сфере государственной и муниципальной службы ${ }^{16}$, соответственно, создание системы противодействия коррупции на уровне организации (как бизнес-организации, так и организации бюджетной, но не входящей в систему органов власти) не предусматривались ${ }^{17}$.

Однако уже в 2012 г. в Законе о противодействии коррупции (на основании, в том числе, разработок ученых — правоведов и рекомендаций научного сообщества (Khabrieva (ed.), 2012:535-536, авторы главы - А.В. Габов, А.Е. Молотников), (Vlasenko (ed.), 2012:181, авторы главы - А.В. Габов, А.Е. Молотников) появились нормы, обязывающие организации (юридические лица) «разрабатывать и принимать меры по предупреждению коррупции» (ст. 13.3 Закона о противодействии коррупции) (Khabrieva (ed.), 2018:371-379).

Согласно указанной статье, меры по предупреждению коррупции, принимаемые в организации, могут включать:

- определение подразделений или должностных лиц, ответственных за профилактику коррупционных и иных правонарушений;

- сотрудничество организации с правоохранительными органами;

- разработку и внедрение в практику стандартов и процедур, направленных на обеспечение добросовестной работы организации;

— принятие кодекса этики и служебного поведения работников организащчиน;

— предотвращение и урегулирование конфликта интересов;

- недопущение составления неофициальной отчетности и использования поддельных документов.

Как видно из приведенного фрагмента, организациям был дан выбор в части применения указанных мер по противодействию коррупции; конкрет-

\footnotetext{
16 То есть использовалось традиционное понимание коррупции как явления, возникающего в связи с использованием служебного положения на государственной службе. Соответствующие определения коррупции легко найти во множестве работ (к примеру, коррупция — «использование государственной должности в личных целях», см.: (Campos, Pradhan, 2010:38).

17 См. первоначальную редакцию Федерального закона от 25 декабря 2008 г. № 273-Ф3 «О противодействии коррупции» // Собрание законодательства РФ. 2008. № 52 (ч. 1). Ст. 6228 (далее - Закон о противодействии коррупции), Национальный план противодействия коррупции на 2010-2011 годы, утвержденный Президентом РФ от 31 июля 2008 г. № Пр-1568 и ряд иных документов.
} 
ные меры не навязывались организациям, к примеру, они могли (но не были обязаны) принять соответствующий кодекс этики ${ }^{18}$.

Дальнейшим развитием этого средства стал Указ Президента Российской Федерации от 2 апреля 2013 г. № 309 «О мерах по реализации отдельных положений Федерального закона «О противодействии коррупции» (пп. «б» п. 25). Этим актом Министерству труда и социальной защиты Российской Федерации было поручено совместно с заинтересованными федеральными органами исполнительной власти и бизнес-объединениями «подготовить методические рекомендации по вопросам, касающимся предупреждения коррупции, в соответствии со статьей 13.3 Федерального закона «О противодействии коррупции».

Соответствующие «Методические рекомендации по разработке и принятию организациями мер по предупреждению и противодействию коррупции» (далее - Методические рекомендации) были утверждены Министерством труда и социальной защиты Российской Федерации 8 ноября 2013 г. ${ }^{19}$

В Методических рекомендациях разработка и принятие кодекса этики и служебного поведения работников организации была отнесена к числу проводимых организацией антикоррупционных мероприятий, элементом корпоративной культуры организации.

В отношении содержания кодекса этики отмечалось, что он «имеет более широкий спектр действия, чем регулирование вопросов, связанных непосредственно с запретом совершения коррупционных правонарушений». Согласно Методическим рекомендациям в такой кодекс следует включить положения, устанавливающие ряд правил и стандартов поведения работников, затрагивающих общую этику деловых отношений и направленных на формирование этичного, добросовестного поведения работников и организации в целом.

Методические рекомендации отмечали, что кодекс этики и служебного поведения может закреплять:

- как общие ценности, принципы и правила поведения (которые могут быть раскрыты и детализированы для отдельных сфер (видов) деятельности),

- так и специальные, направленные на регулирование поведения в отдельных сферах. То есть кодекс этики и служебного поведения может не только декларировать определенные ценности, принципы и стандарты поведения, но $u$ устанавливать правила и процедуры их внедрения в практику деятельности организации.

При этом разработчики Методических рекомендаций справедливо указывали на то, что содержание кодекса этики может быть значительно диффе-

\footnotetext{
${ }^{18}$ Название документа, как думается, большого значения не имеет, важно его содержание. О различного рода кодексах поведения также см.: (Karpovich, Truntsevskii, 2016:78-102).

${ }^{19}$ См.: Методические рекомендации по разработке и принятию организациями мер по предупреждению и противодействию коррупции, available at: https://rosmintrud.ru/docs/mintrud/employment/26 (Accessed 01 February 2020).
} 
ренцировано, в частности «по степени жесткости устанавливаемой регламентациии».

В частности, указывалось, что:

- «с одной стороны, кодекс может закрепить только основные ценности и принципы, которые организация намерена культивировать в своей деятельности»;

— «с другой стороны, кодекс может устанавливать конкретные, обязательные для соблюдения правила поведения».

Соответственно, Методические рекомендации указывали на необходимость разработки кодекса организации «исходя из собственных потребностей, задач и специфики деятельности».

Интересно, что в Методических рекомендациях использование типовых форм при таком составлении оценивалось негативно («использование типовых решений является нежелательным»).

Однако не отвергалось использование типичных подходов для организаций из одной профессиональной сферы деятельности («вместе с тем при подготовке своего кодекса организация может использовать кодексы этики и служебного поведения, принятые в данном профессиональном сообществе»).

Применительно к противодействию коррупции в сфере образования вопрос о кодексе этики нашел свое развитие в Рекомендациях по организации мероприятий, направленных на разработку, принятие и применение Кодекса профессиональной этики педагогическим сообществом, сообщенных письмом Министерства образования и науки РФ от 6 февраля 2014 г. № 09-148 «О направлении материалов».

Отметим, что Федеральный закон от 29 декабря 2012 г. № 273-Ф3 «Об образовании в Российской Федерации» ${ }^{20}$ (далее - Закон об образовании) в перечне обязанностей педагогических работников прямо указывает обязанность «соблюдать правовые, нравственные и этические нормы, следовать требованиям профессиональной этики» (ст. 48 Закона об образовании).

Указанным выше письмом 2014 г. был доведен до сведения организаций в сфере образования Модельный кодекс профессиональной этики педагогических работников организаций, осуществляющих образовательную деятельность.

Согласно указанному Модельному кодексу педагогические работники призваны «исключать действия, связанные с влиянием каких-либо личных, имущественных (финансовых) и иных интересов, препятствующих добросовестному исполнению трудовых обязанностей» и «воздерживаться от поведения, которое могло бы вызвать сомнение в добросовестном исполнении педагогическим работником трудовых обязанностей, а также избегать конфликтных

${ }^{20}$ Федеральный закон от 29 декабря 2012 г. № 273-ФЗ «Об образовании в Российской Федерации» // Собрание законодательства РФ. 2012. № 53 (ч. 1). Ст. 7598. 
ситуаций, способных нанести ущерб его репутации или авторитету организации, осуществляющей образовательную деятельность» (п. 8).

Отдельно в этом документе (п. 10) подчеркивалось, что «педагогическим работникам надлежит принимать меры по недопущению коррупционно опасного поведения педагогических работников, своим личным поведением подавать пример честности, беспристрастности и справедливости» ${ }^{21}$.

Россия не является, к сожалению, пионером в области использования для противодействия коррупции в образовании этических норм. В исследованиях и практике целого ряда зарубежных государств в начале - середине 2000-х гг. была обоснована необходимость использования этических норм, наряду с нормами правовыми, к примеру, Vincent R. Johnson (Johnson, 2008) в работе 2008 г. отмечал: «Basic principles for structuring a legal regime to fight corruption in education can be drawn from other fields of endeavor raising important issues relating to ethics in public life... corruption should be fought with a combination of legal and ethical tools (выделено авторами. - А.Г., О.Я.), including (a) prohibitions of clearly improper conduct, (b) disclosure requirements that expose questionable practices to public scrutiny, and (c) clear statements of aspirational principles» (Johnson, 2008:23-24).

В развитие приведенных нормативных документов и документов, содержащих разъяснения нормативного характера, указывающих на необходимость осуществления мер по противодействию коррупции в организациях в целом и в образовательных организациях в частности, в последние годы мы наблюдаем практику создания образовательными организациями высшего образования различного рода локальных актов, содержанием которых (иногда это отражается и в названии) являются этические нормы.

Целью настоящей работы не является полноценный анализ всех принятых в образовательных организациях России кодексов этики, мы лишь хотели бы осветить несколько принципиальных моментов, связанных с принятием, реализацией указанных кодексов.

Во-первых, практика принятия таких документов как для целей исполнения правовых норм и различного рода разъяснений, носящих нормативный характер, так и для целей предупреждения коррупции в образовательной организации «наложилась» на практику использования локальных актов организации, содержащих этические нормы, для институционализации определенной правовой культуры в организации (Tuguz, Lyausheva, 2013). В отдельных работах об этическом кодексе говорилось как об «основополагающем документе корпоративной культуры организации»; отмечалось, что «появление в совре-

\footnotetext{
${ }^{21}$ Отметим, что после создания Министерства просвещения Российской Федерации действие этого документа было заменено на собственный (см.: письмо Минпросвещения России, Профсоюза работников народного образования и науки РФ от 20 августа 2019 г. № ИП-941/06/484 «О примерном положении о нормах профессиональной этики педагогических работников»).
} 
менной российской действительности этических кодексов, или кодексов корпоративной этики, было обусловлено потребностью руководства компаний, организаций, предприятий в формализации и установлении собственных правил взаимоотношений между сотрудниками внутри организаций и установлению единого подхода, принципов и норм во взаимоотношениях их с «внешним» миром - предприятиями, организациями, физическими лицами»; констатировалось, что «...Цель введения такого внутриорганизационного поведенческого единообразия посредством этического кодекса - обеспечение управляемости коллектива сотрудников, достижение состояния бесконфликтности внутри организации, формирование и поддержание привлекательного имиджа организации во взаимоотношениях с внешней средой, в основе которого привлекательность поведения и взаимодействия каждого из сотрудников и, возможно самое главное, мотивированная мобилизация всех ресурсов на максимальную самоотдачу сотрудников для достижения объединяющих целей организации» (Sidorin, Sidorin, 2015:105).

Следует отметить, что с начала 1990-х гг. получила широкое распространение практика принятия кодексов этики в рамках различных профессиональных страт.

Как отмечается исследователями, «с началом Перестройки, с развитием в стране рыночных отношений и принятием порой несистематизированного и противоречивого законодательства многие профессиональные сообщества, формировавшиеся в 1990-е гг. ощутили потребность в определенном саморегулировании, в частности в создании правил поведения для своих членов» (Finogentova, Polozkov, 2013:16). Исследователи указывают на органичность формирования профессиональной этики, при этом отмечают, что «профессиональная этика не функционирует сама по себе. Для взаимодействия с обществом она должна принять форму этических кодексов. Кодифицированные концепции профессиональной этики являются средством моральной регуляции деятельности сотрудников отдельных организаций, профессионального сообщества в целом» (Safonov, 2013:55).

Во-вторых, принятие локальных актов, содержащих этические нормы, в которых отражена антикоррупционная составляющая, это не единичная, а массовая практика.

Такие документы могут носить различные наименования - Кодекс профессиональной этики педагогических работников (Балтийский федеральный университет им. Иммануила Канта ${ }^{22}$ ), Этический кодекс преподавателя и со-

\footnotetext{
${ }^{22}$ См.: Кодекс профессиональной этики педагогических работников, available at: https://www.kantiana. ru/upload/iblock/9ab/kodeks.pdf (Accessed 03 February 2020).
} 
трудника ДВФУ (Дальневосточный федеральный университет) ${ }^{23}$, Кодекс этики и служебного поведения федерального государственного автономного образовательного учреждения высшего образования «Казанский (Приволжский) федеральный университет» ${ }^{24}$, Этический кодекс МГУ, Кодекс универсанта СПбГУ 25 , Кодекс чести преподавателя РУДН ${ }^{26}$, Кодекс этики университетского сообщества ФГАОУ ВПО «Уральский Федеральный Университет имени первого Президента России Б.Н. Ельцина» ${ }^{27}$.

Можно приводить примеры с иными названиями. На самом деле название здесь не имеет большого значения; оно, скорее, отражает традиции образовательной организации, жизненный и профессиональный опыт, образование и культуру авторов соответствующих документов, желание и возможность охватить тот или иной субъектный состав (здесь, как видно, в одних случаях говорится только о преподавателях, в других - и о сотрудниках, в-третьих - и об обучающихся, в-четвертых - обо всех лицах, связанных отношениями с образовательной организацией или членах университетского сообщества). Важнее названия документа другое:

- все документы содержат наиболее общие требования (можно сказать - принципы) к поведению преподавателей и/или обучающихся (а в ряде случаев - и иных лиц);

- требования антикоррупционного характера, которые содержатся в таких актах, формулируются по-разному, и, кстати, не всегда с использованием слов «коррупция» или «антикоррупционные» или схожих слов.

К примеру, в Кодексе чести преподавателя РУДН указано на требование «не вступать с обучающимися и поступающими в РУДН в отношения протекционизма, в том числе в какие-либо финансово-экономические взаимоотношения, за исключением случаев, предусмотренных законодательством и нормативными документами Университета».

Сходное положение предусмотрено в Кодексе чести обучающегося в РУДН (Приложение к Правилам внутреннего распорядка обучающихся в

\footnotetext{
${ }^{23}$ См.: Этический кодекс преподавателя и сотрудника ДВФУ, available at: https://www.dvfu.ru/upload/ medialibrary/a9f/Этический\%20кодекс\%20преподавателя\%20и\%20сотрудника\%20ДВФУ.pdf (Accessed 02 February 2020).

${ }^{24}$ См.: Кодекс этики и служебного поведения федерального государственного автономного образовательного учреждения и высшего образования Казанский (Приволжский) федеральный университет, available at: https://kpfu.ru/portal/docs/F1352310852/kodeks.etiki.i.sluzhebnogo.povedeniya.pdf (Accessed 03 February 2020).

${ }^{25}$ См.: Кодекс универсанта, available at: https://spbu.ru/openuniversity/documents/kodeks-universanta (Accessed 13 February 2020).

${ }^{26}$ См.: Кодекс чести преподавателя РУДН, available at: http://www.rudn.ru/u/www/files/kodeks-chestiprepodavatelya-rudn.pdf (Accessed 03 February 2020).

${ }^{27}$ См.: Кодекс этики университетского сообщества ФГАОУ ВО «УрФУ имени первого Президента России Б.Н. Ельцина», available at: https://urfu.ru/fileadmin/user_upload/common_files/employee/other/ Kodeks_ehtiki.pdf (Accessed 03 February 2020).
} 
РУД $\left.{ }^{28}\right)$, где указано, что обучающийся не должен вступать с преподавателями и сотрудниками Университета ни в какие финансово-экономические взаимоотношения, не предусмотренные законодательством РФ и нормативными документами Университета.

В Этическом кодексе преподавателя и сотрудника ДВФУ (в части профессиональной этики преподавателя) указаны такие требования: «воздерживаться от отношений с обучающимися в формате «даритель и получатель подарков», «предотвращать ложь, мошенничество, кражи...».

В Кодексе профессиональной этики педагогических работников Балтийского федерального университета им. Иммануила Канта встречаем такие требования: «исключать действия, связанные с влиянием каких-либо личных, имущественных (финансовых) и иных интересов, препятствующих добросовестному исполнению трудовых обязанностей», «воздерживаться от поведения, которое могло бы вызвать сомнение в добросовестном исполнении педагогическим работником трудовых обязанностей, а также избегать конфликтных ситуаций...», не допускать «принятия от обучающихся подарков, целью которых является влияние на результаты образовательного процесса, назначения обучающимся и принятия у них платы за аттестацию или иные образовательные услуги».

В Кодексе этики университетского сообщества ФГАОУ ВПО «Уральский Федеральный Университет имени первого Президента России Б.Н. Ельцина» к числу норм этического поведения любого члена университетского сообщества отнесено (ст. 32) предпринимание мер антикоррупционной защиты.

В Этическом кодексе МГУ указано, что преподаватели и научные сотрудники МГУ должны воздерживаться от таких отношений с учащимися, которые могут препятствовать эффективному обучению и затруднять беспристрастную оценку результатов учебной деятельности (коммерческое партнерство; отношения должника и заимодавца, дарителя и получателя подарков), для учащихся Этический кодекс МГУ предусматривает обязанности не использовать личных или иных связей для получения более высокой оценки или для того, чтобы добиться иных исключений из общего регулирования; не предлагать вознаграждений преподавателям или администрации для того, чтобы облегчить прохождение процедур контроля знаний, умений и навыков, или добиться иных исключений из общего регулирования.

Кодекс универсанта СПбГУ предусматривает запрет оказания неправомерного воздействия на универсантов, используя свое служебное положение, профессиональный или учебный статус, иные обстоятельства для достижения любых целей, признает несовместимым со статусом универсанта использование

\footnotetext{
${ }^{28}$ См.: Приказ ректора об утверждении правил внутреннего трудового распорядка и порядка предоставленя отпусков, available at: http://www.rudn.ru/u/www/files/svedenia_ob_organizasii/Pravila_trud_ rasporyadka_07_09_15.pdf (Accessed 13 February 2020).
} 
недобросовестных приемов и способов при прохождении текущей, промежуточной и итоговой аттестации и ее оценке.

Весьма детально проработан Кодекс этики и служебного поведения ФГАОУ «Казанский (Приволжский) федеральный университет» (и здесь этот документ можно рекомендовать как один из лучших примеров для использования). В качестве принципа деятельности работника вуза здесь указан и такой «не допускать совершение и (или) участие в совершении коррупционных правонарушений в интересах или от имени КФУ, воздерживаться от поведения, которое может быть истолковано окружающими как готовность совершить или участвовать в совершении коррупционного правонарушения в интересах или от имени КФУ», «незамедлительно информировать непосредственного руководителя и (или) лицо, ответственное за реализацию антикоррупционной политики в КФУ, в случае их отсутствия, ректора КФУ:

- о случаях склонения работника к совершению коррупционных правонарушений;

- о ставшей известной работнику информации о случаях совершения коррупционных правонарушений другими работниками, контрагентами КФУ или иными лицами», «сообщать непосредственному руководителю или ректору КФУ о возможности возникновения или возникшем конфликте интересов», «не использовать свое служебное положение для оказания влияния на деятельность КФУ в целях решения вопросов личного характера», «исключать действия (бездействие) связанные с влиянием каких-либо личных, имущественных (финансовых) и иных интересов, препятствующих добросовестному исполнению трудовых обязанностей», «не добиваться прямо или косвенно, в связи с выполнением своих трудовых обязанностей, не предусмотренного законодательством Российской Федерации и локальными актами КФУ получения вознаграждения от иных юридических, физических лиц (подарки, денежное вознаграждение, ссуды, выгоды, услуги, оплату развлечений и иные вознаграждения...» и т.д.

В-третьих, сколь бы ни были подробно описаны в этих документах антикоррупционные требования, они не могут «работать» вне системы других внутренних документов образовательной организации, в которых определяется механизм их реализации, устанавливаются органы, осуществляющие контроль их соблюдения и проч. Такие документы всегда являются частью общей антикоррупционной политики образовательной организации. Во многих образовательных организациях даже принимается отдельный документ - положение об антикоррупционной политике ${ }^{29}$, где могут частично дублироваться и этические требования антикоррупционного характера ${ }^{30}$.

\footnotetext{
${ }^{29}$ В литературе отмечается, что с целью предотвращения коррупционных деяний в сфере высшего образования в каждом вузе должна быть разработана антикоррупционная политика как комплекс взаимосвязанных принципов, процедур и конкретных мер, направленных на предупреждение и предотвращение коррупционных правонарушений со стороны работников вузов, которая являлась бы ло-
} 
В-четвертых, положения документов, содержащих этические нормы, тесно взаимоувязаны с локальными актами образовательных организаций в части предотвращения конфликта интересов, который, как известно, лежит в основе любой коррупции. Такие локальные акты содержат организационный механизм создания и деятельности органов образовательных организаций, направленных на оценку наличия конфликта интересов, его выявление и принятие мер по его устранению. В образовательных организациях распространена практика создания таких органов (комиссий, советов), в компетенцию которого входит контроль за соблюдением требований к поведению учащихся, преподавателей, научных сотрудников и других работников образовательной организации и урегулированию конфликта интересов. Например, в Этическом кодексе Московского государственного университета имени М.В. Ломоносова указано, что администрация, ученые советы МГУ и факультетов совместно с общественными организациями преподавателей, сотрудников и учащихся могут создавать этические комиссии, которые наделены полномочиями по анализу случаев нарушения кодекса и вынесению санкций, в том числе правом ходатайствовать перед руководством университета о применении мер дисциплинарной ответственности по отношению к нарушителям. В РУДН в целях профилактики коррупции и контроля за проведением в университете антикоррупционной политики создан постоянно действующий орган, которым является комиссия по

кальным нормативным актом в сфере противодействия коррупции, обязательным не только для всех работников, но и обучающихся — студентов вуза; основными целями антикоррупционной политики в вузах должны стать следующие цели: минимизация рисков участия научно-педагогических кадров, других работников и обучающихся в коррупционной деятельности; формирование у всех сотрудников, независимо от занимаемой должности, и студентов, единообразного понимания антикоррупционной политики, а именно неприятие коррупции в любых ее формах и проявлениях, см.: (Aliev, Solovykh, 2019:46-50).

${ }^{30}$ К примеру, в Положении об антикоррупционной политике РУДН 2019 г. закреплены обязанности работников и обучающихся университета, связанных с предупреждением и противодействием коррупции: воздерживаться от совершения и (или) участия в совершении коррупционных правонарушений в интересах или от имени университета; воздерживаться от поведения, которое может быть истолковано окружающими как готовность совершить или участвовать в совершении коррупционного правонарушения в интересах или от имени университета; незамедлительно информировать ректора / непосредственного руководителя / руководителя о случаях склонения работника или обучающегося к совершению коррупционных правонарушений; незамедлительно информировать ректора / непосредственного руководителя / руководителя о ставшей известной работнику или обучающемуся информации о случаях совершения коррупционных правонарушений другими работниками, обучающимися, контрагентами организации или иными лицами; сообщить ректору / непосредственному руководителю / руководителю о возможности возникновения либо возникшем у работника или обучающегося конфликте интересов (см.: Положение об антикоррупционной политике федерального государственного автономного образовательного учреждения высшего образования «Российский университет дружбы народов».pdf, available at: http://www.rudn.ru/u/www/files/Polozhenie-ob-antikorrup-tsionnoypolitike-federalnogo-gosudarstvennogo-avtonomnogo-obrazovatelnogo-uchrezhdeniya-visshego-obrazovaniyaRUDN(1).pdf (Accessed 13 February 2020). 
противодействию коррупции ${ }^{31}$. Основными целями комиссии по противодействию коррупции является анализ существующих проблем и угроз в сфере коррупции и, как следствие, выработка подходов к их устранению, основанных на действующем федеральном законодательстве и локальных нормативных актов. Кроме того, в целях совершенствования профессиональных компетенций научно-педагогических кадров, административного персонала, сотрудников правоохранительных органов и других заинтересованных лиц в области противодействия коррупции в образовании в РУДН предусмотрена программа повышения квалификации «Противодействие коррупции в сфере образования».

В-пятых, следует обратить внимание на трансформацию правил (норм), которые содержат документы, содержащие этические нормы. Перед нами изначально были нормы не правовые, а иные виды социальных норм ${ }^{32}$ : нормы морали (или этические нормы), регулирующие поведение лиц, на определенный период времени устойчиво связанных с образовательной организацией (то есть перед нами то, что в теории права обычно именуют корпоративными нормами или нормами организаций (Cherdantsev, 1999:329; Marchenko, 2007:116-117; Kulapov, 2019:222-223) и много других работ). В той части, в которой они были направлены на формирование внутренней культуры организации, они чаще всего не связывались с действием права ${ }^{33}$. А вот в части антикоррупционных правил они были направлены на усиление действия норм законов о противодействии коррупции, а в определенной части и на дополнение таких норм. Отсюда весьма интересный тренд на развитие указанных норм, содержащихся в документах организаций, в том образовательных: в настоящем мы наблюдаем постепенное перерастание этических норм в нормы правовые. Строго говоря, граница между регуляторами здесь «стирается» и название регулятора - «этические нормы», «нормы этики» - становится не в полной мере адекватным его роли и месту в регулировании отношений; сам регулятор утрачивает самостоятельное значение: перед нами не этические нормы, нормы морали, а нормы правовые; их нарушение есть основание для ответственности.

\footnotetext{
${ }^{31}$ См.: Положение о Комиссии по противодействию коррупции федерального государственного образовательного учреждения общественного образования «Российский университет дружбы народов», available at: http://www.rudn.ru/u/www/files/Polozhenie-o-Komissii-po-protivodeystviyu-korruptsii-federalnogo-gosudarstvennogo-avtonomnogo-obrazovatelnogo-uchrezhdeniya-visshego-obrazovaniya-RUDN.pdf (Accessed 13 January 2020).

${ }^{32}$ В некоторых работах используют термин «неправовые социальные нормы» (см.: Marchenko, 1996:265).

${ }_{33}$ Отметим, что здесь есть и иные точки зрения. Так, А.В. Сидорин и В.В. Сидорин (Sidorin, Sidorin, 2015) полагают, что любой этический кодекс организации «как локальный акт дополняет и конкретизирует законодательство, приводит к «общему знаменателю» поведение и отношение к профессиональным обязанностям, а в отдельных случаях — и мировоззрение сотрудников с разным уровнем образования, различных социальных, культурных и возрастных групп с учетом особенностей организации», см.: (Sidorin, Sidorin, 2015:105).
} 
Уже в Модельном кодексе указывалось (п. 16), что «соблюдение педагогическим работником положений Кодекса может учитываться при проведении аттестации педагогических работников на соответствие занимаемой должности, при применении дисциплинарных взысканий в случае совершения работником, выполняющим воспитательные функции, аморального проступка, несовместимого с продолжением данной работы, а также при поощрении работников, добросовестно исполняющих трудовые обязанности».

Здесь интересно и место приведенного п. 16 в структуре Модельного кодекса: он находится в разделе III «Ответственность за нарушение положений Кодекса». Усиление нормативного характера положений кодексов этики возможно через включение обязанности их исполнения всеми работниками образовательной организации в устав организации.

Статья 336 Трудового кодекса («Дополнительные основания прекращения трудового договора с педагогическим работником») указывает, что помимо оснований, предусмотренных Трудовым кодексом и иными федеральными законами, основаниями прекращения трудового договора с педагогическим работником является в том числе и «повторное в течение одного года грубое нарушение устава организации, осуществляющей образовательную деятельность». Соответственно, наличие в уставе обязанности соблюдать кодекс этики (а это делается практически везде в разных формах, хотя ст. 25 Закона об образовании в части обязательных требований к уставу образовательной организации на это не указывает) приведет к возможности использования его норм для принятия конкретных правового характера решений ${ }^{34}$.

Таким образом, закон, ответственность - это гаранты действия положений кодексов этики; уже нельзя, как ранее, сказать (Этический кодекс МГУ 2009 г. $^{35}$ ), что «исполнение данного кодекса обеспечивается на основе нравственного самоконтроля работников и учащихся университета, авторитетного мнения академического сообщества, проявляющего себя через формальные и неформальные средства выражения». Показательно, что в отдельных случаях принятие кодексов этики создает значительный конфликтный потенциал в об-

\footnotetext{
${ }^{34}$ Пока же отметим, что практикой является включение обязанностей, вытекающих из антикоррупционных требований в трудовые договоры. Причем делается это на системной и плановой основе. Например, в Плане антикоррупционных мероприятий СПбГУ на 2018-2020 годы от 22 августа 2018 г. № 8303/1 предусмотрено включение в трудовые договоры должностных лиц СПбГУ, взаимодействующих с гражданами (в том числе с представителями сторонних организаций), обязанности письменного уведомления представителя работодателя об обращениях в целях склонения к совершению коррупционных действий, а также включение в трудовые договоры работников СПбГУ обязательства уведомлять об обстоятельствах, свидетельствующих о возможном конфликте интересов (см.: Приказ об утверждении Плана антикоррупционных мероприятий СПбГУ на 2018-2020 годы, available at: https://spbu.ru/openuniversity/documents/ob-utverzhdenii-plana-antikorrupcionnyh-meropriyatiy-spbgu-na2018-2020 (Accessed 13 January 2020).

${ }^{35}$ См.: Этический кодекс МГУ, available at: https://socio.msu.ru/documents/eticheskij_kodeks_MSU.pdf (Accessed 13 January 2020).
} 
разовательной организации ${ }^{36}$; вряд ли принятие документа вызывало бы напряжение, если бы вопрос исчерпывался только моральным воздействием.

Исходя из изменившегося значения положений кодексов этики, фактического перерастания этих положений в полноценные правовые нормы, следует сказать, что не могут рассматриваться только в контексте средств предупреждения коррупции (превенции), это теперь и полноценное средство противодействия коррупции.

Важно отметить, что такие документы уже сложно именовать в узком смысле корпоративными, поскольку требования таких документов активно «навязывается» контрагентам организаций через включение в договоры т.н. антикоррупционных оговорок. Как нам думается, теория права пока недостаточное внимание уделяет указанному правовому феномену.

\section{Выводы исследования}

Подводя итоги, отметим следующее.

Требования законодательства о противодействии коррупции, о необходимости разрабатывать и принимать меры по предупреждению коррупции в каждой организации, созданной и действующей на территории Российской Федерации, находят практическое воплощение в деятельности большинства крупных организаций в Российской Федерации, в том числе и образовательных организаций.

Распространенной стала практика принятия различного рода кодексов (сводов, правил) поведения (этики, антикоррупционных), в которых организации устанавливают этические правила поведения для лиц, состоящих с ними в различных отношениях. Эта практика распространяется на партнеров таких организаций через использование в заключаемых договорах т.н. «антикоррупционных оговорок».

Соответствующая практика по принятию мер по предупреждению и противодействию коррупции становится все более распространенной в образовательных организациях высшего образования. Среди мер по предупреждению и противодействию коррупции в таких организациях активно используются кодексы этики, которые содержат чаще всего наиболее общие требования (принципы), прежде всего, к преподавателям образовательных организаций, хотя, как показывает анализ, многие такие организации значительно расширяют субъектный состав лиц, на которых такие документы распространяются.

Такие документы (кодексы этики, этические кодексы) в силу довольно общего характера их предписаний действуют в единой системе с другими ло-

\footnotetext{
${ }^{36}$ См.: Кодексы этики вузов: разбор полетов // https://trv-science.ru/2015/12/08/kodeksy-etiki-vuzovrazbor-poletov/ (Accessed 02 February 2020).
} 
кальными актами образовательной организации, прежде всего теми, которые направлены на разрешение конфликтов интересов.

С нашей точки зрения, целесообразно, чтобы Минобрнауки России, совместно с Минтрудом России проанализировали складывающуюся практику принятия и применения локальных актов в образовательных организациях для целей предупреждения и противодействию коррупции с целью выделения лучших практик и разработки практических предложений по их внедрению в деятельность образовательных организаций.

\section{Библиографический список / References}

Aliev, V.M., Solovykh, N.N. (2019) Corruption related crimes in higher education: issues of countering. Russian Investigator. (4), 46-50. (in Russian).

Алиев B.M., Соловых H.Н. Преступления коррупционной направленности в сфере высшего образования: проблемы противодействия // Российский следователь. 2019. № 4. C. 46-50.

Campos, E., Pradhan, S. (eds.) (2010) Mnogolikaya korruptsiya: Vyyavlenie uyazvimykh mest na urovne sektorov ekonomiki i gosudarstvennogo upravleniya [The Many Faces of Corruption: Identifying Vulnerabilities at the Sector and Economy Levels]. Translation from English. Moscow, Alpina Publishers. (in Russian).

Многоликая коррупция: Выявление уязвимых мест на уровне секторов экономики и государственного управления / Под ред. Э. Кампоса и С. Прадхана; Пер. с англ. М.: Альпина Паблишерз, 2010. $551 \mathrm{c}$.

Cherdantsev, A.F. (1999) Teoriya gosudarstva i prava: Uchebnik dlya vuzov [Theory of State and Law: A Textbook for High Schools]. Moscow, Yurait Publ. (in Russian).

Черданщев А.Ф. Теория государства и права: Учебник для вузов. М., Юрайт. 1999. $432 \mathrm{c}$.

Gorshkov, M.K., Markin V.V. (2012) Problemy protivodeistviya korruptsii v rossiiskom obshchestve: sotsiologicheskii aspekt [Problems of anti-corruption in Russian society: sociological aspect]. Problems of anti-corruption in Russian society: sociological aspect / Legal problems of anti-corruption (materials of the International scientific conference. Moscow, November 2, 2011). Rel. edited by L. V. Andrichenko, O. O. Zhuravleva. Moscow, Institute of legislation and comparative law under the Government of the Russian Federation; publishing house "Jurisprudence” Publ. (in Russian).

Горшков М.К., Маркин В.В. Проблемы противодействия коррупции в российском обществе: социологический аспект / Правовые проблемы противодействия коррупции (материалы Международной научной конференции. Москва, 2 ноября 2011 г.) / отв. ред. Л.В. Андриченко, О.О. Журавлева. М., Институт законодательства и сравнительного правоведения при Правительстве Российской Федерации; ИД «Юриспруденция», 2012. 280 с.

Damaskin, O.V. (2009) Korruptsiya: Sostoyanie, prichiny, protivodeistvie [Corruption: State, causes, opposition]. Moscow, Publishing House "Triumfal'naya arka" Publ. (in Russian). Дамаскин О.В. Коррупция: Состояние, причины, противодействие. М.: ИД «Триумфальная арка». 2009. 304 с.

Efimov, V.S., Lapteva, A.V. (2011) Higher Education in Russia: Challenges of the XXI Century. Journal of Siberian Federal University. Humanities \& Social Sciences. 1 (2011 4), 143-154. 
Finogentova, O., Polozkov, Ye. (2013) The system of ethical codes of modern Russia. IKBFU's Vestnik. Ser. the Humanities and Social Science. Issue 09. 15-21. (in Russian).

Финогентова О.Е., Полозков Е.В. Система этических кодексов в современной России // Вестник Балтийского федерального университета им. И. Канта. 2013. Вып. 9. C. $15-21$.

Glendinning, I., Orim, St.-M., King, A. (2019) Policies and Actions of Accreditation and Quality Assurance Bodies to Counter Corruption in Higher Education. Project Report. February 2019, available at: https://www.chea.org/sites/default/files/pdf/CHEA_CorruptionReport-Final-underlines.pdf (Accessed 03 March 2020).

Heyneman, St.P. (2004) Education and corruption. International Journal of Educational Development, 24, 637-648, available at: https://www.researchgate.net/publication/44838168_ Education_and_Corruption (Accessed 03 March 2020).

Heyneman, S.P. (2014) How Corruption Puts Higher Education at Risk. International Higher Education. (75), 8-12. (in Russian).

Хейнеман С.П. Как коррупция ставит высшее образование под угрозу // Международное высшее образование. 2014. № 75. С. 8-12.

Johnson, V.R. (2008) Corruption in Education: A Global Legal Challenge. Santa Clara Law Review, 1(48), available at: http://digitalcommons.law.scu.edu/lawreview/vol48/iss1/1 (Accessed 09 March 2020).

Karpovich, O.G., Truntsevskii, Yu.V. (2016) Teoriya i sovremennye praktiki komplaensa. Mirovye modeli protivodeistviya kriminal'nym ugrozam: monografiya [Theory and modern practices of compliance. World models of countering criminal threats: a monograph]. Moscow, UNITI-DANA: Zakon i pravo Publ. (in Russian).

Карпович О.Г., Трунцевский Ю.В. Теория и современные практики комплаенса. Мировые модели противодействия криминальным угрозам: монография. М.: ЮНИТИДАНА: Закон и право. 2016. 407 с.

Khabrieva, T.Ya. (ed.) (2012) Korruptsiya: priroda, proyavleniya, protivodeistvie [Corruption: nature, manifestations, opposition]. Moscow, Publishing House "Yurisprudentsiya" Publ. (in Russian).

Коррупция: природа, проявления, противодействие / отв. ред. академик РАН Т.Я. Хабриева. М.: ИД «Юриспруденция». 2012. 688 с.

Khabrieva, T.Y. (ed.) (2016) Combating Corruption: New challenges: Monograph. Ivanov, S.B., Khabrieva, T.Y., Tchikhantchin, Yu.A. and etc. managing editor Khabrieva, T.Y. Moscow, The Institute of legislation and comparative law under the government of the Russian Federation. INFRA-M Publ. www.dx.doi.org/10.12737/21335. (in Russian).

Противодействие коррупции: новые вызовы: монография / С.Б. Иванов, Т.Я. Хабриева, Ю.А. Чиханчин и др.; отв. ред. Т.Я. Хабриева. М.: Институт законодательства и сравнительного правоведения при Правительстве Российской Федерации: ИНФРА-М, 2016. 376 c. www.dx.doi.org/10.12737/21335.

Khabrieva, T.Y. (ed.) (2018) Nauchno-prakticheskii kommentarii k Federal'nomu zakonu ot 25 dekabrya 2008 g. № 273-Fz "O protivodeistvii korruptsii” (postateinyi) [Scientific and practical commentary on the Federal Law of December 25, 2008 No. 273-Fz "On Combating Corruption” (article by article)]. Khabrieva T.Y., Gabov A.V., Tsirin A.M. and etc. Moscow, The Institute of legislation and comparative law under the government of the Russian Federation. (in Russian).

Научно-практический комментарий к Федеральному закону от 25 декабря 2008 г. № 273-Ф3 «О противодействии коррупции» (постатейный) / Т.Я. Хабриева, А.В. Габов, А.М. Цирин и др.; отв. ред. Т.Я. Хабриева. М., Институт законодательства и сравнительного правоведения при Правительстве Российской Федерации, 2018. 424 с. 
Kolodko, Gzhegozh V. (2000) Ot shoka $k$ terapii. Politicheskaya ekonomiya postsotsialisticheskikh preobrazovanii [From shock to therapy. Political Economy of Post-Socialist Transformations]. Moscow, ZAO “Zhurnal Expert” Publ. (in Russian).

Колодко Гжегож В. От шока к терапии. Политическая экономия постсоциалистических преобразований. М., ЗАО «Журнал Эксперт», 2000. 392 с.

Kulapov, V.L. (2019) Teoriya gosudarstva i prava: Uchebnik [Theory of State and Law: A Textbook]. Saratov: Federal State Budgetary Educational Establishment of Higher Education "Saratov State Law Academy" Publ. (in Russian).

Кулапов В.Л. Теория государства и права: Учебник. Саратов: Изд-во ФГБОУ ВО «Саратовская государственная юридическая академия», 2019. 452 с.

Marchenko, M.N. (1996) Teoriya gosudarstva i prava [Theory of State and Law]. Uchebnik [Textbook]. Moscow, Yuridicheskaya literatura Publ. (in Russian).

Марченко М.Н. Теория государства и права. Учебник. М.: Юрид. лит., 1996. 432 с.

Marchenko, M.N. (ed.) (2007) Obshchaya teoriya gosudarstva i prava [General theory of state and law]. Akademicheskii kurs trekh tomakh. Tom 2: Pravo [Academic course of three volumes. Volume 2: Right]. 3rd ed. rev. and add. Moscow, Norma Publ. (in Russian). Общая теория государства и права. Академический курс трех томах. Том 2: Право / отв. ред. М.Н. Марченко. 3-е изд. перераб. и доп. М.: Норма, 2007. 816 с.

Plyugina, I.V. (2016) Anti-Corruption Legal Mechanisms in Education Sector. Journal of Russian Law. (12). 123-133. DOI: 10.12737/22730. (in Russian).

Плюгина И.В. Правовые механизмы предупреждения коррупции в сфере образования // Журнал российского права. 2016. № 12. C. 123-133. DOI: 10.12737/22730.

Putilo, N.V., Volkova, N.S. (ed.) (2015) Obrazovatel'noe zakonodatel'stvo Rossii. Novaya vekha razvitiya: monografiya. Educational legislation of Russia. New milestone of development: monograph. L. V. Andreichenko, V. L. Baranov, B. A. Bulaevsky et al.; ed. by N. V. Putilo, N. S. Volkova; Institute of legislation and comparative law under the Government of the Russian Federation. Moscow, ID Jurisprudence Publ. (in Russian).

Образовательное законодательство России. Новая веха развития: монография / Л.В. Андриченко, В.Л. Баранков, Б.А. Булаевский и др.; отв. ред. Н.В. Путило, Н.С. Волкова; Институт законодательства и сравнительного правоведения при Правительстве Российской Федерации. М., ИД Юриспруденция. 2015. 480 с.

Safonov, K.B. (2013) Ethics of the professions and the corporate ethos. Perm university herald. Series “Philosophy. Psychology. Sociology”. 1 (13), 54-57. (in Russian).

Сафонов К.Б. Этические кодексы: проблемы создания и применения // Вестник Пермского университета. Философия. Психология. Социология. 2013. Выпуск 1 (13). C. 54-57.

Sidorin, A.V., Sidorin, V.V. (2015) The code of ethics of the university as the basis of corporate culture of technical university. Standard model. University Management: Practice and Analysis. (1), 104-119. (in Russian).

Сидорин A.B., Сидорин В.B. Этический кодекс вуза как основа корпоративной культуры технического Университета. Типовая модель // Университетское управление: практика и анализ. 2015. №1. С. 104-119.

Stavilo, S.P. (2008) Istinnye i lozhnye metody formirovaniya komfortnogo obucheniya i ikh vliyanie na mirovozzrenie lichnosti v usloviyakh globalizatsii [True and false methods for the formation of comfortable learning and their impact on the worldview of a person in a globalized world]. Juridical Education and Science. (2), 13-18. (in Russian).

Ставило С.П. Истинные и ложные методы формирования комфортного обучения и их влияние на мировоззрение личности в условиях глобализации // Юридическое образование и наука. 2008. № 2. С. 13-18. 
Tuguz, F.K., Lyausheva, S.A. (2013) Ethical code of the University as a resource for students' socialization. The Bulletin of Adyghe State University: Series 1: Regional Studies: Philosophy, History, Sociology, Law, Political Science, Cultural Studies. (4), 164-173, available at: https://cyberleninka.ru/article/n/eticheskiy-kodeks-universiteta-kak-resurs-sotsializatsiistudentov (Accessed 07 March 2020). (in Russian).

Тугуз Ф.К., Ляушева С.А. Этический кодекс университета как ресурс социализации студентов // Вестник Адыгейского государственного университета. Серия 1: Регионоведение: философия, история, социология, юриспруденция, политология, культурология. 2013. № 4 (130). С. 164-173, available at: https://cyberleninka.ru/article/n/ eticheskiy-kodeks-universiteta-kak-resurs-sotsializatsii-studentov (Accessed 07 March 2020).

Vlasenko, N.A. (ed.) (2012) Legal means of combating corruption: scientific-practical guide. Vlasenko, N.A., Gracheva, S.A. Rafalyuk, E.E. and etc. Moscow, The Institute of legislation and comparative law under the government of the Russian Federation. Jurisprudence Publ. (in Russian).

Правовые средства противодействия коррупции: научно-практическое пособие / Н.А. Власенко, С.А. Грачева, Е.Е. Рафалюк и др.; отв. ред. Н.А. Власенко. М.: Институт законодательства и сравнительного правоведения при Правительстве Российской Федерации: ИД «Юриспруденция». 2012. 344 с.

\section{Об авторах:}

Габов Андрей Владимирович - член-корреспондент Российской академии наук (РАН), доктор юридических наук, Заслуженный юрист Российской Федерации

ORCID ID: 0000-0003-3661-9174; ResearcherID: Q-9357-2017

e-mail: gabov@igpran.ru

Ястребов Олег Александрович - доктор юридических наук, доктор экономических наук, профессор, директор Юридического института, заведующий кафедрой административного и финансового права Российского университета дружбы народов (РУДН)

ORCID ID: 0000-0003-4943-6940

e-mail: yastrebov_oa@rudn.university

\section{About the authors:}

Andrey V. Gabov - Corresponding Member of the Russian Academy of Sciences (RAS), Doctor of Legal Sciences, honored lawyer of the Russian Federation

ORCID ID: 0000-0003-3661-9174; ResearcherID: Q-9357-2017 e-mail: gabov@igpran.ru

Oleg A. Yastrebov - Doctor of Legal Sciences, Doctor of Economic Sciences, Professor, Director of the Law Institute, Head of the Department of Law Institute RUDN

ORCID ID: 0000-0003-4943-6940

e-mail: yastrebov_oa@rudn.university 